\title{
Chemical Composition and Antioxidant Activity of Portuguese Diospyrus Kaki Fruit by Geographical Origins
}

\author{
Ana Ferreira Vinha \\ Health Technologie Research Center (CITS - IPSN/CESPU), Portugal \\ E-mail: anafvinha@gmail.com \\ Marta Oliveira Soares \\ Health Technologie Research Center (CITS - IPSN/CESPU), Portugal \\ E-mail: martaoliveirasoares@gmail.com \\ Teresa Herdeiro \\ Health Technologie Research Center (CITS - IPSN/CESPU), Portugal \\ E-mail: therdeiro@yahoo.com \\ Marisa Machado \\ Health Technologie Research Center (CITS - IPSN/CESPU), Portugal \\ E-mail: smrmachado@gmail.com
}

\author{
Received: May 27, $2011 \quad$ Accepted: June 23, $2011 \quad$ Online Published: December 21, 2011 \\ doi: $10.5539 /$ jas.v4n2p281 \\ URL: http://dx.doi.org/10.5539/jas.v4n2p281
}

\begin{abstract}
Lately, several studies have demonstrated the health benefits associated with natural compounds consumption. Fruit phenolics, lycopene and ascorbic acid, have strong antioxidant, anti-inflammatory, antimugenic and anticarcinogenic activities. In the present study parameters related to fruit quality and climacteric conditions, such as color, moisture, $\mathrm{pH}$, water activity, total phenolic compounds, ascorbic acid and lycopene content were analyzed. Diospyros kaki $c v$. chocolate fruits were extracted with different solvents, such as methanol, ethanol and water. Total polyphenolics of each extract determined by Folin-Ciocalteu method were found to be higher in methanolic extract (106.2 mg/100g sample) and lower in ethanol (21.9 mg/100g sample) considering Diospyros fruits with peel. The antioxidant activity (AA) was evaluated by an in vitro model system trough 1,1-diphenyl-2-picrylhydrazyl radical scavenging capacity (DPPH') assay. Significant variations were found in the levels of these parameters according to different geographic regions. It was possible to describe correlations between the antioxidant compounds (polyphenolics, ascorbic acid and lycopene) and the antioxidant activity. Aqueous solvent was more effective on the extraction of antioxidant compounds from Portuguese Diospyros fruits with 52\% radical scavenging activity. Results support the importance of Diospyros kaki cv. chocolate fruits, Portuguese cultivar, as a functional food with high antioxidant potential that may have beneficial effects against oxidative human damage.
\end{abstract}

Keywords: Portuguese Diospyros kaki, Antioxidant activity, (DPPH) assay, Total polyphenolics, Lycopene, Geographic origin

\section{Introduction}

Fruits and vegetables have acquired the status of functional foods in Mediterranic diet (Vinha et al., 2002; Alonso et al., 2004). They seem to be capable of delivering health benefits besides fulfilling physiological needs. Epidemiological data as well as in vitro studies strongly suggest that foods containing bioactive phytochemicals 
with antioxidation potential have strong protective effects against some major diseases, including cancer and cardiovascular diseases (Clinton, 1998; Jang, et al., 2007; Céspedes, et al., 2008).

Diospyros fruit is highly nutritious compared to other fruits. The protective action of fruits has been attributed to the presence of antioxidants, especially antioxidants vitamins, including ascorbic acid, $\beta$-carotene (Giraldi, et al., 2003; Céspedes, et al., 2008; Chen, et al., 2008). Besides carotenoids, Diospyros kaki fruits contain a variety of natural antioxidants (Davies \& Hobson, 1981; Clinton, 1998; Davey, et al., 2000; Kim, et al., 2006).

Antioxidants are compounds that can delay oxidation of lipids or other molecules by inhibiting the beginning or propagation of oxidative chain reactions (Velioglu, et al., 1998). According to some authors, the antioxidant content of orange/red fruit mostly depends on genetic, environmental factors and ripening stage (Kim, et al., 2006; Chen, et al., 2008). Fruit ripening is a complex, genetically programmed process that culminates in dramatic changes in color, texture, flavor and chemical compositions (Vinha, et al., 2005). It has been shown that ripening processes and storage temperature can severely affect the final nutrient composition of fruits (Davey, et al., 2000; Javanmardi \& Kubota, 2006; Kim, et al., 2006; Patthamakanokporn, et al., 2008). Lycopene, which is responsible for the orange/red color of Diospyros kaki (Clinton, 1998; Giraldi, et al., 2003), changes significantly between cultivars, stage of maturity and growing conditions (Stahl \& Sies, 1996; 2003) and also is regarded as an antioxidant with high biological activity among humans (Sahlin, et al., 2004).

The genus Diospyros belongs to the family Ebenaceae and comprises about 500 species distributed in the tropical and temperate zone, including Portugal. This fruit is very appreciated by the Portuguese population and is highly nourishing, in comparison with other seasonal results. Besides his nourishing value, Diospyros is described for its applications for medicinal and therapeutic ends. Unfortunately, few researches on its bioactive activities have been reported, especially on bioactive compounds of the Portuguese fruit from different geographic areas. A single fruit weighs $250 \mathrm{~g}$ and can reach up to $610 \mathrm{~g}$. Therefore, many attempts have been made to extend the storage and shelf life (Turk, 1993).

The aim of this study was to evaluate chemical profile of Portuguese Diospyros kaki through different soil and climatic conditions in different geographic regions. At the same time, the content of total phenolics, ascorbic acid and lycopene were also determined. The radical scavenging activity of the Diospyros by employing the DPPH radical scavenging method was also analyzed. Although there are some reports regarding antioxidant activity of fruits and peels of persimmon (Jung, et al., 2005; Lee, et al., 2008; Fukai, et al., 2009), no work has been done on the comparative research about chemical profile, bioactive compounds content and antioxidant capacity of Portuguese Diospyros kaki and their relation with geographic regions.

\section{Material and Methods}

\subsection{Samples}

Diospyros kaki fruits $c v$. chocolate were collected from different locations, north (V. N. Famalicão), center (Guarda) and south (Portimão) of Portugal, at the same time, November 2009. Just about 5Kg of Diospyros kaki fruits were randomly harvest from 10 different trees in the same plantation area from different geographic plantation, as mentioned above and according to the seasonal growth. Freshly collected fruits were cleaned and prepared according to requirements of the intended analysis and stored at $4^{\circ} \mathrm{C}$. Samples were prepared in two groups, with and without peel, in order to evaluate the antioxidant compounds lost with skin removal and also because persimmon fruits may be consumed with or without peel, and after homogenized using a wet blender (National; model: MX-291N) for 1 minute. Homogenized samples were transferred into an air-tight container and kept at $-20^{\circ} \mathrm{C}$ before extracts preparation.

\subsection{Qualitative Parameters}

Diospyros kaki samples were analyzed on moisture content, soluble solids, $\mathrm{pH}$, water activity $\left(\mathrm{a}_{\mathrm{w}}\right)$ and maturity index (color). Total soluble solids were quantified in a fruit puree using an Atago, NAR-3T refractometer, expressed as ${ }^{\circ}$ Brix, a quick estimate of sugar content. $\mathrm{pH}$ value was measured by using a $\mathrm{pH}$-meter (Hanna instruments 8417), for three times. Water content was determined by gravimetric assay. The $5 \mathrm{~g}$ of each fresh sample in porcelain capsule were placed in stove (WTC binder Klasse 2.0, Tuttlingen, Germany) at $105^{\circ} \mathrm{C} \pm 1{ }^{\circ} \mathrm{C}$, followed from regular weighting up to constant weight and results expressed in percentage of water (\%). The water activity $\left(\mathrm{a}_{\mathrm{w}}\right)$ was measured using a Rotronic Hygropalm 9 VCD model. Three color reading were taken from each sample, after homogenization of whole fruits, using a Minolta Chromameter II Reflectancia CR-2000 (Minolta Limited, Milton Keynes, UK). The* (red-green) and $b^{*}$ (yellow-blue) values were used to calculate the hue angle value, $\tan ^{-1}\left(b^{*} / a^{*}\right)$, which provides information about color index (color intensity) of fruit samples. 


\subsection{Antioxidant Compounds Quantification}

\subsubsection{Total Polyphenolic Content Assay}

The amount of total polyphenolic was determined according to Jang (2007) using Folin-Ciocalteu reagent. Total polyphenolic compounds were extracted using three different solvents; water at ambient temperature (aqueous), methanol (MeOH 80\%) and ethanol (EtOH 80\%) for one hour, in order to assess the extraction effect in fruits antioxidant properties. A $1 \mathrm{~g}$ of fresh sample was added of $50 \mathrm{ml}$ of each solvent, under constant agitation for 1 hour. Filtration took place under vacuum and checked for a final volume of $100 \mathrm{ml}$. A volume of $0.2 \mathrm{ml}$ of extracts $(1 \mathrm{mg} / \mathrm{ml})$ was added of $0.5 \mathrm{ml}$ of Folin-Ciocalteu reagent for $3 \mathrm{~min}$ at room temperature. After, $0.2 \mathrm{ml}$ of sodium carbonate $6 \%$ was added and gently mixed. After standing at room temperature for 120 min, absorbance was read at $720 \mathrm{~nm}$ using a UV-Vis spectrophotometer. Total polyphenolic were quantified by calibration curve obtained from measuring the absorbance of a known catequin concentration standard. Concentrations were expressed as milligrams of catequin equivalents per $100 \mathrm{~g}$ of fresh weight.

\subsubsection{Ascorbic Acid Assay}

Ascorbic acid content was determined according to the modified 2,6-dichlorophenolindophenol (DIP) method (Franck et al., 2003). Each fruit sample (5 g) was extracted using $20 \mathrm{ml}$ of oxalic acid (0.4\%) for 1 hour. Extracts were filtered and $5 \mathrm{ml}$ was added to $10 \mathrm{ml}$ of oxalic acid and $1 \mathrm{ml}$ of HCL (1M). Quantification was obtained from a standard curve within the linear range of $0-0.8 \mathrm{mg}$ ascorbic acid per $\mathrm{mL}$.

\subsubsection{Lycopene Assay}

Lycopene content was determined according to Sadler et al. (1990). Briefly, $5 \mathrm{~g}$ of homogenized sample was extracted adding $50 \mathrm{ml}$ of a mixture of hexane/acetone/ethanol $(2: 1: 1, \mathrm{v} / \mathrm{v} / \mathrm{v})$ for 30 minutes. The absorbance of supernatant (hexane layer) containing lycopene was read using Beckman DU-64 spectrophotometer at $472 \mathrm{~nm}$ (specific to lycopene). Absolute hexane was used as blank. The amount of lycopene in fruit was then estimated by the using the formula:

$$
\text { Lycopene }(\mu \mathrm{g} / \mathrm{g})=\left[\left(\operatorname{Axvx} 10^{6}\right) /(3.450 \times \mathrm{W} \times 100)\right]
$$

Where $\mathrm{v}$ is the amount of hexanes $(\mathrm{ml}), \mathrm{W}$ the weight of fruit sample $(\mathrm{g}), \mathrm{A}$ the absorvance at $472 \mathrm{~nm}$ and 3.450 is the extinction coefficient.

\subsection{Radical Scavenging Activity using DPPH'Assay}

DPPH was used for the estimation of antioxidant capacity based on the reaction of a specific reagent with electron donating or hydrogen radical producing anti-oxidant compounds. The radical scavenging activity of the Diospyros fruit extracts was determined as previously described (Jang et al., 2007). Briefly, $5 \mathrm{ml}$ of DPPH in $\mathrm{MeOH}\left(0.03 \mathrm{~g} / \mathrm{dm}^{3}\right)$ were added to $0.05 \mathrm{ml}$ of polyphenolic extracts for 30 minutes in the dark. Absorbance (A) was measured every 10 minute over a 60 minute time period at $517 \mathrm{~nm}$ on a UV spectrophotometer UV-60. Radical scavenging activity was expressed as inhibition percentage and calculated using the equation:

\subsection{Statistical Analysis}

$$
\left.\% \text { Radical scavenging activity }=\left[\left(\mathrm{A}_{\text {Control }}-\mathrm{A}_{\text {Sample }}\right) / \mathrm{A}_{\text {Control }}\right)\right] \mathrm{X} 100 .
$$

Statistical analysis was performed using Prisma 5. Data of all analysis were expressed as mean \pm standard error mean (SEM) from three independent samples in triplicate. Results were statistically evaluated by variance analysis (ANOVA). Statistical differences with P-values under 0.05 were considered significant and means were compared by $95 \%$.

\section{Results and Discussion}

Various parts of different plants could be used as fruits or vegetables for human consumption. They can be roots, tubers, bulbs, stems and shoots, flowers, leaves and fruits, or pods and seeds. It is crucial to study and learn about the plant cell and compounds responsible for flavor, texture and color to obtain reliable information about the effects of different treatments on these quality characteristics. However, geographic variation may also contribute for same specific nutritional and chemical variation in fruits pulp. All the compounds present in each fruit and its quantitative evaluation constitute an individual "fingerprint" in this case, a chemical profile that characterizes each fruit. This profile is not constant and there are several factors influencing their variation. Other factors that may influence the chemical profile are climate, sun exposure, soil nature and agricultural techniques. Physiochemical results are presented in Table 1.

$<$ Table $1>$ 
Weight loss variation of Diospyros kaki fruit was not significantly different with peel and without peel $(\mathrm{p}>0.05)$. It appears that fruit water content is in average around $80 \%$. Geographic region did not affect the moisture percentage. $\mathrm{pH}$ values ranged, in all samples collected North of Portugal, with statistical significance $(\mathrm{p}<0.05)$ compared with samples collected in Center and South. Values from North Diospyros with peel and without peel were 6.05 and 5.95, respectively; samples from the South have lower values, 5.66 and 5.68 from samples with peel and without. Water activity values were similar in all samples with mean values corresponding to $95.5 \%$, $(\mathrm{p}>0.05)$. However, with regard to soluble solids, Center samples, collected in Guarda, showed significantly diffrences among Diospyros with and without peel $(\mathrm{p}<0.05)$, did not observed the same relationship in samples collected in North and in South of Portugal. Regarding to color angle $\left(\mathrm{h}^{\circ}\right)$ determination, in statistical analysis was observed a no significance results $(p>0.05)$ between all samples when compared with geographical regions of cultivation. However, it is important to note that all samples with peel showed a greater color angle than samples without peel, with the exception of two samples from the South. The color angle value for peel sample in South showed a lower angle, wich means more color intensity, than without peel fruit (74.93 and 79.20, respectively), reinforcing the idea that the climate and sun exposure has an influence on fruit color that might be related with fruit chemical composition, namely the lycopene content. These results are according to other published studies (Sadler et al., 1990; Franck et al., 2003; Furlong et al., Jang et al., 2007; Halilova \& Yildiz 2009).

The polyphenolic compounds and carotenoids are directly related to the organoleptic characteristics of fruit, particularly in color and flavor. The determination of phenolic compounds level in plant or fruit tissues is the initial step of any physiological functionality investigation for further stimulus to their consumption (Furlong et al., 2003). According with some authors the quantity and the composition of bioactive compounds, such ascorbic acid, lycopene and phenolic compounds present in fruits are influenced by genotype, extraction procedure and environmental conditions (Howard et al., 2003; Caldwell et al., 2005; Hinneburg \& Neubert 2005; Mukhopadhyay et al., 2006).

$<$ Table 2>

Examining the results presented in Table 2, Diospyros fruit samples with peel in North and Center of Portugal have higher amount of ascorbic acid than samples without peel, collected in the same regions, ranging from $0.9479 \mathrm{mg} / 100 \mathrm{~g}$ to $1.3079 \mathrm{mg} / 100 \mathrm{~g}$ and $0.6834 \mathrm{mg} / 100 \mathrm{~g}$ to $1.1290 \mathrm{mg} / 100 \mathrm{~g}$, respectively. South samples did not show any differences between them, with similar levels with peel $(1.1268 \mathrm{mg} / 100 \mathrm{~g})$ and without peel $(1.1290 \mathrm{mg} / 100 \mathrm{~g})(\mathrm{p}>0.05)$. The most significant lost in ascorbic acid was observed by peel remotion in Diospyros from North $(\mathrm{p}<0.001)$. Usually, ascorbic acid content is directly related with $\mathrm{pH}$ value in a direct proportion. The weather in Center is smoother between seasons and in South is warmer. However these results are according with mean $\mathrm{pH}$ values from samples collected in different geographic regions.

Fresh fruits contain antioxidant compounds like vitamin A, $\beta$-carotene, lycopene, lutein, zeaxanthin and cryptoxanthin. These compounds function as protective scavengers against oxygen-derived free radicals and reactive oxygen species (ROS) that play a role in aging and various disease processes. Fruits are also a very good source of vitamin C, another powerful antioxidant. Regular consumption of foods rich in vitamin $\mathrm{C}$ helps body develop resistance against infectious agents and scavenge harmful, pro-inflammatory free radicals.

In Table 3 is represented lycopene content obtained in different Diospyros kaki fruit samples studied through different geographical areas from Portugal.

$<$ Table 3>

Lycopene values ranged between $3.635 \mathrm{mg} / 100 \mathrm{~g}$ and $8.064 \mathrm{mg} / 100 \mathrm{~g}$, showing higher concentration in whole with peel $(\mathrm{p}<0.05)$. These results may be of greater interest considering others studies reported, mainly the difference on its concentration. For instance, in Saijo, concentrations of 0.7 and $3.90 \mathrm{mg} / 100 \mathrm{~g}$ were reported by Homnava et al. (1990) and Kondo et al. (2004) respectively, probably owing to environmental effects and/or yearly fluctuations. Persimmons are described as a very good source of lycopene, superior to most of commonly consumed fruits, with a standard content of $0.159 \mathrm{mg} / 100 \mathrm{~g}$ fresh weight (USDA). Hence the wide variability of lycopene content could be attributed to genotype effect and could also depend on environmental factors. An interesting aspect is the increased level of lycopene in samples from different regions. Lycopene content increases from north to south reinforcing results published by Kim et al. (2006) and Takahashi et al. (2006) showing increases in carotenoids and polyphenols concentrations in fruit skins compared to those found in pulps. The same authors had concluded that lycopene concentrations were related with different growing regions, particularly to those with higher sun exposure. A great interest has recently been focused on lycopene due to its preventive activity against several pathologies, such as cardiovascular disease (Rao 2002), hepatic fibrogenesis 
(Kitade et al., 2002), solar light induced erythema (Stahl \& Sies 2002) and some cancer types, such as prostate, gastrointestinal and epithelial (Leong \& Shui 2002; Livny et al., 2002). Finally, it is also important to consider the synergic action of carotenoids with other bioactive compounds present in Diospyros kaki fruit, like total polyphenolic content.

Polyphenolic compounds represent a large and important group of abundant secondary plant metabolites in fruit. Total polyphenolic content of Diospyros kaki fruit extracts were obtained using methanol $80 \%$, ethanol $80 \%$ and aqueous (water) solvents are shown in Table 4.

Table 4. Influence of geographic region on total polyphenolics content (mg Ec $/ 100 \mathrm{~g}$ sample) of Diospyros kaki frui with peel and without peel using three different solvent extracts.

The maximum extractable total polyphenolics content were recorded in methanol solvent, followed by aqueous and ethanol solvents, respectively. The extraction method is very important in experimental procedure, so we studied different extraction using the three different solvents showing a significant result between them $(\mathrm{p}<$ 0.001). Total polyphenolic content differences were significant $(\mathrm{p}<0.001)$, however, total polyphenolic content in Diospyros kaki fruit seems to be higher in south samples, with and without peel.

Results in Table 4 reveal, that peel samples showed higher values than those obtained without peel, in which concentrations ranged between 21.9 and $106.2 \mathrm{mg} / 100 \mathrm{~g}$ for with peel Diospyros samples and 18.7 and 47.0 $\mathrm{mg} / 100 \mathrm{~g}$ to removed peel samples. These concentrations variation increase in a direct proportion with geographic regions $(p<0.001)$ and seems to be higher that polyphenol contents found in Triumph fruits harvested in different years (about $1.4 \mathrm{mg} / 100 \mathrm{~g}$ ) and analyzed by the same procedure (Park et al., 2006). Fruits from South have higher total polyphenolic levels than North fruits contain lower levels of total polyphenolics, demonstrating that climatic conditions are important for their development in fruits metabolism.

The antioxidant activity of Dyospiros fruits has been chemically assessed by determining the radical scavenging activity through the 1,1-diphenyl-2-pycrylhydrazil (DPPH') method (Leong \& Shui 2002; Kondo et al., 2004; Chen et al., 2008; Del Bubba et al., 2009). The relationship between total polyphenolics content and the radical scavenging activity of the Portuguese fruits along with controls (BHT) was investigated based on scavenging free radicals species recognized by antioxidants. According to Leong \& Shui (2002) this method has been a useful tool to evaluate the antioxidant capacity of fruits. The DPPH inhibition levels by discoloration of synthetic antioxidant BHT were used as positive control for comparison between samples and to validate analytical method. Statistical analysis had shown a positive and highly significant relationship between total polyphenolics content and radical scavenging activity $(p<0.05)$. Aqueous extracts from south revealed higher activity (52\% and $44.8 \%$ from Diospyros fruits with peel and without peel, respectively, both in south samples). Less antioxidant activity was observed in methanolic extract corresponding to $34.8 \%$ sample with peel and $15 \%$ without peel. Ethanolic extract had revealed the lower antioxidant ability (33\% and $18 \%$, with peel and without peel, respectively). These values were higher than those found in Diospyros fruit varieties analyzed in Italy (Del Bubba et al., 2009) but lower than Israeli persimmon fruits (Jung et al., 2005). Again, it appears that the study of antioxidant activity is directly related to the content of polyphenolic compounds, giving more emphasis to the importance of the extraction process, manely on the solvent used.

$<$ Figure 1 $>$

By statistical analysis it was found a relationship between the concentrations of polyphenolics and antioxidant activity of the same sample, as there is a relationship between the origin of persimmon fruits and antioxidant activity $(p<0.001)$. A good correlation was registed between catequin and DPPH values $\left(R^{2}\right.$ ranges between 0.86 and 0.89 ).

\section{Conclusion}

Some researchers have shown that persimmon is one of the most bioactive fruits. In this work the role of Diospyros kaki fruits as a source of primary and secondary metabolites (vitamin C, lycopene and polyphenols), was studied. The main function of antioxidants is the delaying of the oxidation process to other molecules by inhibiting the initiation or propagation of oxidizing chain reactions by free radicals reducing oxidative damage to human body. The occurrence of such oxidative damage may be a significant causative factor in the development of many chronic diseases, such as cancer and cardiovascular diseases. Several epidemiological studies have shown a negative association between intake of fruits and certain diseases. Diospyros kaki have shown to possess a high free radical scavenging activity. This study indicates that the antioxidant activity of Diospyros fruits is related to polyphenolic compounds, ascorbic acid and lycopene content and the removal of fruits peel decreases their amounts. This study also highlighted the influence of different geographic regions on chemical composition 
of fruits. The Diospyros kaki is a highly nutritious fruit in comparison to other fruits, and currently carries great importance in research for medicinal purposes, for its potential in promoting public health. Apart from all that was mentioned earlier, this study becomes a pioneer one, since there are no records of a similar study in Portuguese Diospyros kaki.

\section{References}

Alonso, M. G., Teresa, S. P., Buelga, S. C., \& Gonzalo, J. C. R. (2004). Evaluation of the antioxidant properties of fruits. Food Chem, 84, 13-18. http://dx.doi.org/10.1016/S0308-8146(03)00160-2

Caldwell, C. R., Britz, S. J., \& Mirecki, R. M. (2005). Effects of temperature, elevated carbon dioxide, and drought during seed development on the isoflavone content of dwarf soybean [Glycine max (L.) Merrill] grown in controlled environments. J Agric Food Chem, 53, 1125-1129. http://dx.doi.org/10.1021/jf0355351

Céspedes, C. L., Mohammed, E. H., Pavon, N., \& Alarcon, J. ( 2008). Antioxidant and cardioprotective activities of phenolics extracts from fruits of Clilean blackberry Aristotelia chilensis (Elaeocarpaceae), maqui. Food Chem, 107, 820-829. http://dx.doi.org/10.1016/j.foodchem.2007.08.092

Chen, X. N., Fan, J. F., Yue, X., Wu, X. R., \& Li, L. T. (2008). Radical scavenging activity and phenolic compounds in persimmon (Diospyros kaki L. cv. Mopan). $J$ Food Sci, 73(1), 24-28. http://dx.doi.org/10.1111/j.1750-3841.2007.00587.x

Clinton, S. K. (1998). Lycopene: chemistry, biology, and implications for human health and disease. Nutr Rev, $56,35-51$.

Davey, M. W., Montagu, M. V., Inzé, D., Sanmartin, M., Kanellis, A., Smirnoff, N., et al. (2000). Plant L-ascorbic acid: chemistry, function, metabolism, bioavailability and effects of processing. J Sci Food Agric, 80, 825-860. http://dx.doi.org/10.1002/(SICI)1097-0010(20000515)80:7

Davies, J. N., \& Hobson, G. E. (1981). The constituints of tomato fruit - the influence of environment, nutrition and genotype. Crit Rev Food Sci Nutr, 15(3), 205-280.

Del Budda, M., Giordani, E., Cincinelli, A., Checchini, L., \& Galvan, P. (2009). Nutraceutical properties and sugars contents in astrigent persimmons durino on-tree growth and ripening and in response to different postharvest treatments. J Food Comp Anal, 22, 668-677. http://dx.doi.org/10.1016/j.jfca.2009.02.015

Frack, C., Baetens, M., Lammertyn, J., Scheerlinck, N., Davey, M. W., \& Nicolai, B. M. (2003). Ascorbic acid mapping to study core breakdown development in "Conference" pears. Postharvest Biol Technol, 30(2), 133-142. http://dx.doi.org/10.1016/S0925-5214(03)00108-X

Fukai, S., Tanimoto, S., Maeda, A., Fukuda, H., Okada, Y., \& Nomura M. (2009). Pharmacological activity of compounds extracted from persimmon peel (Diospyros kaki THUNB.) $J$ Oleo Sci, 58, 213-219. http://dx.doi.org/10.5650/jos.58.213

Furlong, E. B., Colla, E., Bortolato, D. S., Baisch, A. L. M., \& Souza-Soares, L. A. (2003). Avaliação do potencial de compostos fenólicos em tecidos vegetais. Vetor Rio Grande, 13, 105-114.

Giraldi, C. L., Parussolo, A., Danieli, R., Corrent, A. R., \& Rombaldi, C. (2003). Conservação de caqui (Diospyros kaki L.), cv. Fuyu, pela aplicação de 1-metilciclopropeno. Rev Brasil Frutic, 25(1), 54-56. http://dx.doi.org/10.1590/S0100-29452003000100016

Hinneburg, I., \& Neubert, R. H. (2005). Influence of extraction parameters on the phytochemical characteristis of extracts from buckwheat (Fagopyrum esculentum) herb. $J$ Agric Food Chem, 53(1), 3-7. http://dx.doi.org/10.1021/jf049118f

Holilova, H., \& Yildiz, N. (2009). Does climate change have an effect on proline accumulation in promegranate (Punica granatum L.) fruits? Scientific Res Essay, 4(12), 1543-1546. Available online at http://www.academicjournals.org/SRE

Homnava, A., Payne, J., Koehler, P., \& Eitenmiller, R. (1990). Provitamin A (alpha-carotene, beta-carotene and beta-cryptoxanthin) and ascorbic acid content of japonese and American persimmons. J Food Quality, 13, 85-95. http://dx.doi.org/10.1111/j.1745-4557.1990.tb00009.x

Howard, L. R., Clark, J. R., \& Brownmiller, C. (2003). Antioxidant capacity and phenolic content in blueberries as affected by genotype and growing season. $J$ Sci Food Agric, 83, 1238-1247. http://dx.doi.org/10.1002/jsfa.1532 
Jang, H. D., Chang, K. S., Huang, Y. S., Hsu, C. L., Lee, S. H., \& Su, M. S. (2007). Principal phenolic phytochemicals and antioxidant activities of three chinese medicinal plants. Food Chem, 103, 749-756. http://dx.doi.org/10.1016/j.foodchem.2006.09.026

Javanmardi, J., \& Kubota, C. (2006). Variation of lycopene, antioxidant activity, total soluble solids and weight loss of tomato during postharvest storage. Postharvest Biol Technol, 41, 151-155. http://dx.doi.org/10.1016/j.postharvbio.2006.03.008

Jung, S. T., Park, Y. S., \& Zachwieja, Z. (2005). Some essential phytochemicals and the antioxidant potential in fresh and dried persimmon. J Food Sci Nutr, 56, 105-113. http://dx.doi.org/10.1080/09637480500081571

Kim, S. Y., Jeong, S. M., \& Kim, S. J. (2006). Effect of heat treatment on the antioxidative and antigenotoxic activity of extracts from persimmon (Diospyros kaki L.) peel. Biosci Biotechnol Biochem, 70(4), 999-1002. http://dx.doi.org/10.1271/bbb.70.999

Kitade, Y., Watanabe, S., Masaki, T., Nishiok, M., \& Nishino, H. (2002). Inhibition of liver fibrosis in LEC rats by a carotenoid, lycopene, or herbal medicine, Sho-saiko-to. Hepatol Res, 22(3), 196-205.

Kondo, S., Yoshikawa, H., \& Katayama, R. (2004). Antioxidant activity in astringent and non-astringent persimmons. J Hortic Sci Biotechnol, 79, 390-394. http://dx.doi.org/10.1016/j.envexpbot.2004.06.001

Lee, Y. A., Cho, E. J., \& Yokozawa, T. (2008). Protective effect of persimmon (Diospyros kaki) peels proanthocyanidin against oxidative damage under $\mathrm{H}_{2} \mathrm{O}_{2}$-induced cellular senescence. Biol Pharm Bull, 31, 1265-1269. http://dx.doi.org/10.1248/bpb.31.1265

Leong, L. P., \& Shui, G. (2002). An investigation of antioxidant capacity of fruits in Singapure markets. Food Chem, 76, 69-75. http://dx.doi.org/10.1016/S0308-8146(01)00251-5

Livny, O., Kaplan, I., Reifen, R., Polak-Charcon, S., Madar, Z., \& Schwartz, B. (2002). Lycopene inhibits proliferation and enhances gap-junction communication of KB-1 human oral tumor cells. J Nutr, 132(12), 3759-3854. http://dx.doi.org/0022-3166/02

Mukhopadhyay, S., Luthria, D. L., \& Robbins, R. J. (2006). Optimization of extraction process for phenolic acids from black cohosh (Cimicifuga racemosa) by pressurized liquid extraction. J Sci Food Agric, 86, 156-162. http://dx.doi.org/10.1002/jsfa.2326

Park, Y. S., Jung, S. T., Kang, S. G., Delgrado-Licon, E., Ayala, A. L. M., \& Tapia, M. S. (2006). Drying of persimmons (Diospyros kaki L.) and the following changes in the studies bioactive compounds and the total radical scavenging activities. $L W T, 39,748-755$. http://dx.doi.org/10.1016/j.lwt.2005.05.014

Patthamakanokporn, O., Puwastien, P., Nitithamyong, A., \& Sirichakwal, P. P. (2008). Changes of antioxidant activity and total phenolic compounds during storage of selected fruits. J Food Comp Anal, 21(3), 241-248. http://dx.doi.org/10.1016/j.jfca.2007.10.002

Rao, A. V. (2002). Lycopene, tomatoes and the prevention of coronary heart disease. Exp Biol Med, 227(10), 908-913.

Sadler, G., Davis, J., \& Dezman, D. (1990). Rapid extraction of lycopene and $\beta$-carotene from reconstituted tomato paste and pink grapefruits homogenates. J Food Sci, 55, 1460-1461. http://dx.doi.org/10.1111/j.1365-2621.1990.tb03958.x

Sahlin, E., Savage, G. P., \& Lister, C. E. (2004). Investigation of the antioxidant properties of tomatoes after processing. J Food Comp Anal, 17(5), 635-647. http://dx.doi.org/10.1016/j.jfca.2003.10.003

Stahl, W., \& Sies, H. (2003). Antioxidant activity of carotenoids. Molecular Aspects of Medicine, 24, 345-351. http://dx.doi.org/10.1016/S0098-2997(03)00030-X

Stahl, W., \& Sies, H. (2002). Carotenoids and protection againts solar UV radiation. Skin Pharmacol Appl Skin Physiol, 15(5), 291-296. http://dx.doi.org/10.1159/000064532

Stahl, W., \& Sies, H. (1996). Lycopene: a biologically important carotenoid for humans? Arch of Biochem Biophys, 336 (1), 1-9. http://dx.doi.org/10.1006/abbi.1996.0525

Takahashi, M., Watanabe, H., \& Kikkawa, J. (2006). Carotenoids extraction from japonese persimmons (Hachiya kaki) peels by supercritical $\mathrm{CO}_{2}$ with ethanol. Anal Sci, 22, 1441-1447. http://dx.doi.org/10.2116/analsci.22.1441

Turk, R. (1993). The cold storage of persimmon harvested at different maturities and the effect of different $\mathrm{CO}_{2}$ application on fruit ripening. Acta Hort, 343, 190-194. 
USDA. Nutritional Nutrient Database for Standard Reference. http://www. nal.usda.gov.

Velioglu, Y. S., Mazza, L., Gao, L., \& Oomah, B. D. (1998). Antioxidant activity and total phenolics in selected fruits, vegetables and grain products. J Agric Food Chem, 46, 4113-4117. http://dx.doi.org/10.1021/j99801973

Vinha, A. F., Ferreres, F., Silva, B. M., Valentão, P., Gonçalves, A., Pereira, J. A., et al. (2005). Phenolic profile of portuguese olive fruits (Olea europaea L.): influences of cultivar and geographical origin. Food Chem, 89, 561-568. http://dx.doi.org/10.1016/j.foodchem.2004.03.012

Vinha, A. F., Silva, B. M., Andrade, P. B., Seabra, R. M., Pereira, J. A., \& Oliveira, B. (2002). Development and evaluation of an HPLC/DAD method for the analysis of phenolic compounds from olive fruits. $J$ Liquid Chrom \& Related Technol, 25(1), 151-160.

Table 1. Influence of geographic region and presence of fruit peel on moisture (\%), soluble solids contents ( ${ }^{\circ}$ Brix), $\mathrm{pH}$ values, water activity $(\%)$ and angle value $\left({ }^{\circ} \mathrm{h}\right)$ of Portuguese Diospyros kaki fruit, $c v$. chocolate

\begin{tabular}{|l|l|l|l|l|}
\hline & & \multicolumn{3}{|l|}{ Geographic region from Portugal } \\
\hline Chemistry Characterization & Sample preparation & North $^{*}$ & Center $^{*}$ & South $^{*}$ \\
\hline \multirow{2}{*}{ Moisture (\%) } & Peel with & $79.5 \pm 0.05$ & $80.1 \pm 0.12$ & $79.4 \pm 0.15$ \\
\cline { 2 - 5 } & Peel without & $82.4 \pm 0.07$ & $80.0 \pm 0.02$ & $80.3 \pm 0.35$ \\
\hline $\mathrm{pH}$ & Peel with & $6.05 \pm 0.02$ & $5.86 \pm 0.09$ & $5.66 \pm 0.04$ \\
\hline \multirow{3}{*}{ Soluble solids ( ${ }^{\circ}$ Brix) } & Peel without & $5.95 \pm 0.04$ & $5.90 \pm 0.03$ & $5.68 \pm 0.01$ \\
\hline \multirow{3}{*}{$\mathrm{a}_{\mathrm{w}}(\%)$} & Peel with & $1.90 \pm 0.02$ & $1.80 \pm 0.03$ & $1.85 \pm 0.01$ \\
\cline { 2 - 5 } & Peel without & $1.90 \pm 0.04$ & $1.90 \pm 0.02$ & $1.85 \pm 0.01$ \\
\hline \multirow{3}{*}{ Hue angle value $\left({ }^{\circ} \mathrm{h}\right)$} & Peel with & $95.7 \pm 0.01$ & $95.2 \pm 0.01$ & $95.2 \pm 0.02$ \\
\cline { 2 - 5 } & Peel without & $95.4 \pm 0.02$ & $95.1 \pm 0.03$ & $95.8 \pm 0.01$ \\
\cline { 2 - 5 } & Peel with & $77.7 \pm 0.07$ & $73.3 \pm 0.12$ & $74.9 \pm 0.04$ \\
\cline { 2 - 5 } & Peel without & $81.2 \pm 0.05$ & $78.6 \pm 0.08$ & $79.2 \pm 0.12$ \\
\hline
\end{tabular}

${ }^{*}$ All values are expressed as means \pm S.D. in triplicate measures. ${ }^{\dagger}$ Compare results between columns, peel with and without. "Compare results between rows, geographic regions. Means in same column or rows with the same supercript were not significantly different $(\mathrm{p}>0.05)$ with different superscript were significantly different $(\mathrm{p}<$ $0.05)$.

Table 2. Influence of geographic region and presence of peel Diospyros fruit on ascorbic acid content.

\begin{tabular}{|l|l|c|c|c|}
\hline & & \multicolumn{3}{|l|}{ Geographic areas from Portugal } \\
\hline & Sample preparation & North & \\
\hline \multirow{2}{*}{ Ascorbic acid $(\mathrm{mg} / 100 \mathrm{~g})$} & Peel with & Center $*$ & South $^{\text {ns }}$ \\
\cline { 2 - 5 } & Peel without $^{*}$ & $0.9479 \pm 0.02$ & $1.3079 \pm 0.07$ & $1.1268 \pm 0.01$ \\
\hline
\end{tabular}

Values expressed are means \pm S.D. of triplicate measurements. ${ }^{\dagger} \mathrm{p}<0.001 ;{ }^{\ddagger} \mathrm{p}<0.01 ;{ }^{\mathrm{ns}} \mathrm{p}>0.05$. ${ }^{*}$ North/Center ${ }^{*}$ North/South $* ;{ }^{* *}$ North/Center $;{ }^{* *}$ North/South $+;$ Center/South ${ }^{\text {ns }}$.

Table 3. Influence of geographic region and peel on lycopene of Diospyros kaki fruit

\begin{tabular}{|c|c|c|c|c|}
\hline & & \multicolumn{3}{|c|}{ Geographic areas from Portugal } \\
\hline & Sample preparation & North $^{\dagger}$ & Center ${ }^{\dagger}$ & South $^{\dagger}$ \\
\hline \multirow{2}{*}{$\begin{array}{l}\text { Lycopene } \\
\text { (mg/100 g) }\end{array}$} & Peel with ${ }^{*}$ & $4.418 \pm 0.09$ & $7.295 \pm 0.04$ & $8.064 \pm 0.03$ \\
\hline & Peel without ${ }^{* *}$ & $3.635 \pm 0.04$ & $4.986 \pm 0.01$ & $5.349 \pm 1.2$ \\
\hline
\end{tabular}

Values expressed are means \pm S.D. of triplicate measurements. ${ }^{*}$ Compare results between same columns, peel with and without peel samples with different superscript were significantly different $(p<0.001)$; ${ }^{\dagger}$ Compare results between rows with different superscript were significantly different $(p<0.05)$, comparing different geographic regions from Portugal. 
Table 4. Influence of geographic region on total polyphenolics content (mg Ec/100g sample) of Diospyros kaki frui with peel and without peel using three different solvent extracts

\begin{tabular}{|c|c|c|c|c|}
\hline \multicolumn{5}{|c|}{ Geographic areas from Portugal } \\
\hline Sample fruit preparation & Solvent & North $^{*}$ & Center $^{*}$ & South $^{*}$ \\
\hline \multirow{3}{*}{ Peel With ${ }^{\dagger}$} & Ethanol & $21.9 \pm 2.43$ & $35.9 \pm 1.62$ & $79.3 \pm 1.34$ \\
\hline & Methanol & $39.0 \pm 1.23$ & $52.5 \pm 10.6$ & $106.2 \pm 2.80$ \\
\hline & Water & $30.9 \pm 5.19$ & $54.1 \pm 0.92$ & $99.3 \pm 1.83$ \\
\hline \multirow{3}{*}{ Peel Without: } & Ethanol & $18.7 \pm 0.84$ & $24.3 \pm 5.75$ & $26.8 \pm 4.40$ \\
\hline & Methanol & $20.2 \pm 1.20$ & $41.4 \pm 1.31$ & $47.0 \pm 2.39$ \\
\hline & Water & $21.1 \pm 4.88$ & $38.6 \pm 3.78$ & $39.2 \pm 0.48$ \\
\hline
\end{tabular}

All values are expressed as means \pm S.D. in triplicate measures. ${ }^{*}$ Compare results between columns, peel with and without, observed with different solvent extractor. Different superscript were significantly different $(\mathrm{p}<$ 0.05 ); $;$ Compare results between rows, with same solvent extractor by comparison different geographic areas, with different superscript were significantly different $(\mathrm{p}<0.05)$.

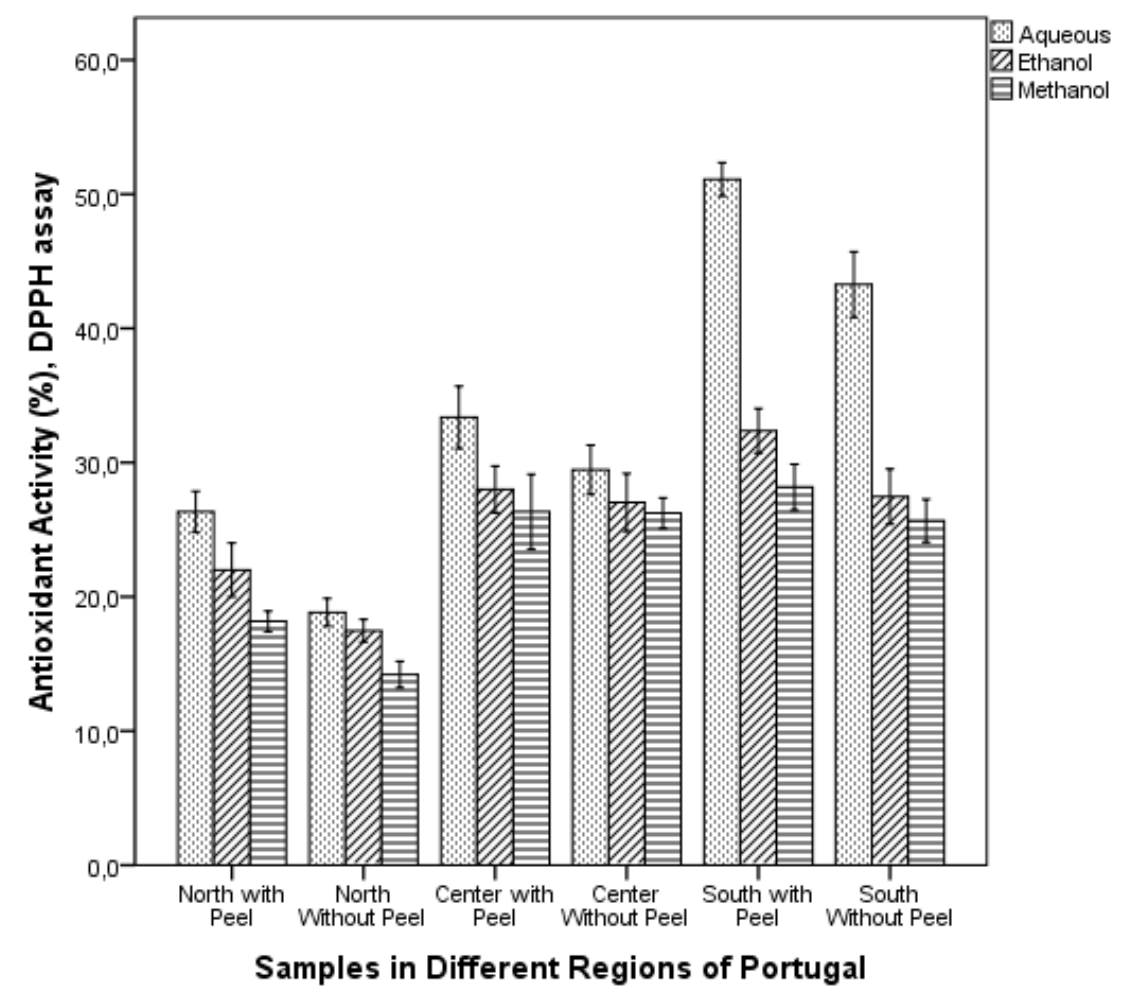

Error bars: $+/-1 \mathrm{SD}$

Figure 1. The antioxidant activity values of Portuguese Diospyros kaki fruits using the radical scavenging activity DPPH" method. N (north samples - peel and without peel); C (center samples - peel and without peel); S (south samples - peel and without peel) 